る現象はこの領域における粒界弱化の解消と直接対応す るものと結論しでよいであろう.Fig. 9 亿よれば再熱過 程の $573 \mathrm{~K}$ 付近までは，P の料界偏析におよぼす応力の 影掣は諰められない， $573 \mathrm{~K}$ をてえると応力の影響が現 われ，その程度は温度の上昇にともなって大きくなる。 応力の影管は $823 \mathrm{~K}$ 付近で極大となり，さらに温度が 上昇すると減少する。 しかし $873 \mathrm{~K}$ 保持過程において P の粒界偏析量は減少するものの，応力の影帮自体は持続 している．すなわち応力が存在するととによって昇温過 程における P の粒界偏析が著しく助長され，保持過程 における P の粒界倔析の解消が㧕制される。とのこと 加前迹の予備応力の存在によって粒界破面率の減少がさ またげられる現象（Fig. 5）の原因と結論してよいであ ろう。

\section{7. 結言}

インプラント方式の再熱割れ試験法（定荷重型）に よって3種の耐熱鐝の割れ試験を行い，破断面に観察さ れる粒界破面の割合を基にして䊀界の弱化現象を検討し た.さらに粒界破烄現象之 $\mathrm{P}$ の粒界偏析および $\mathrm{HAZ}$ の軟化の関連を考察し，以下の結論を得た。

(1) 再熱割れは粒界破面を呈する場合が多いのである が，粒界破面でない場合もありうる，すなわち，定荷重
型割れ試験における限界応力 $\sigma_{C L}$-crit 付近の低い灾力 において粒内割れが生じ，粒界割れは梁められない，こ のような割れは $873 \mathrm{~K}$ に長時間保持されてた後に発珄す る。応力が增加すると粒界割れが発生するようになり， 割れ発生時期は著しく早くなり，873 K 到達㭙付近と なる

(2) 㫒温過程において旧オーステナイト粒界へ偏析し た $\mathrm{P}$ は, $873 \mathrm{~K}$ 保持過程において再び粒内へ㹡散する. このために $873 \mathrm{~K}$ 保持の時間経過に伴って粒界破面辣 が減少するあのと考えられる。

(3) 昇温過程における P の粒界倔析は応力によって 助長される。ささらに恒温保持過程におりる $\mathrm{P}$ の偏析の 解消は応力によって掘滞する。

\section{参 考 献}

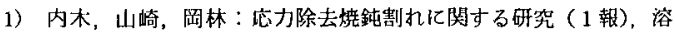
接学会誌, 33-9 (1964), 710

2）鈴水，互置ら：Cr-Mo 鋼の再熱割れ保関する研究（第 5 報）, 溶接紫会論文集，2-1 (1984)，47-54

3）小角，牧野ら：リンの粒界偏析量分析法としての粒界腐食法の検 討，金属学全誌，45-10 (1981)，1093-1101

4) J. Suzuki, K. Tamaki et al. : Effect of Restraint Stress on Crack-initiating Temperature of Reheat cracking of Cr-Mo Steels, Trans. JWS., 17-2 (1986) 164-170

\title{
残留応力の整理パラメータ*
}

異種材料の界面接合部に生ずる残留応力について（第 1 報）

寺崎 俊夫**, 瀬尾 健二***, 平居 孝之****

\begin{abstract}
Dominating Parameters of Residual Stress Distribution, - Reidual Stress in Bonded Dissimilar Materials, Part 1--
\end{abstract}

by Toshio Terasaki**, Kenji Seo***, and Takayuki Hirai****

This paper deals with parameters which dominate residual stress produced by bonded two dissimilar materials. Parameters were derived from theories of elastisity and heat conduction. The validity of parametrers was proved by using Boundary Element Method (BEM). The residual stress at the neighbourhood of bond line in similar body is the same value at a point of similarity. This conclusion is important for making clear the effect of a specimen size on a material strength.

Key Words: Dissimilar materials, Residual stress, Material strength, BEM, Parameter, Elastisity

\section{1. 緒}

言

異種材料を接合した界面には接合母材の物理的性賀・ 機械的性筫の相違により残留応力が発生する. 界面に生 ずる残留応力を数値解析により熱弾塑性解析するととは 実用上において重要である. しかし，材料定数や継手寸 法が残留応力にいかに影響を与えるかを検討する場合に

\footnotetext{
*原稿受付 昭和62年 3 月 23 日 昭和 62 年 2 月第 7 回界面接合研究委 貣会で発表

**正 員 九州工業大学 Member, Kyushu Institute of Technology

***正 員 姫路工業大学 Member, Himeji Institu of Techno$\log y$

****非会真 大分大学 Ohita University
}

は熱弾塑性数值解析よりあ弾性理論に基づく数值解析の 方が優れている，例えば，残留応力を整理するパラメ一 夕を明らかにする場合には弾性理論は工学上において有 意義であると思われる。 Bogy の研究による之, 異種材 料に外荷重力゙作用したときの応力は次に示す Dunder's Composite Parameter である $\beta, \delta$ により整理され $3^{1-4)}$

$$
\begin{aligned}
& \delta=\left\{\Gamma\left(x^{A}+1\right)-\left(\kappa^{B}+1\right)\right\} /\left\{\Gamma\left(\kappa^{A}+1\right)+\left(x^{B}+1\right)\right\} \\
& \beta=\left\{\Gamma\left(x^{A}-1\right)-\left(x^{B}-1\right)\right\} /\left\{\Gamma\left(\kappa^{A}+1\right)+\left(\kappa^{B}+1\right)\right\}
\end{aligned}
$$

ただし, $\Gamma=G^{B} / G^{A}, G=E /\{2(1+\nu)\} \kappa=(3-\nu) /(1+\nu)$

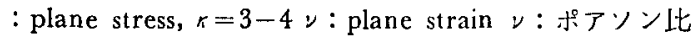
$E$ ：ヤング率 添え字 A，B は材料 A，B 意味する. 本研究では最初に，異種材料の接合時に生ずる残留応 


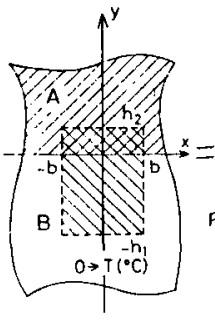

(a)

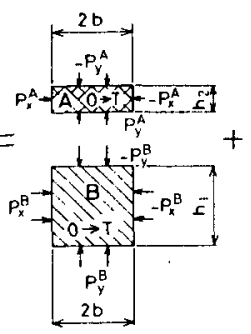

(b)

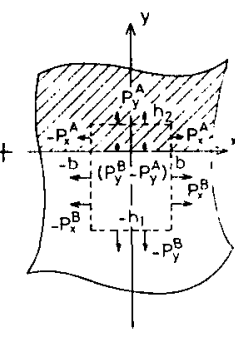

(c)
Fig. 1 Method of calculating residual stress

力を整理するパラメータを弾性理論に基ついて明らかに している. 次に，有限板の異種材料の接合時に生ずる残 留応力を境界要素法を用いて数值解析し, 整理パラメー タの有效性を示した。

\section{2. 残留応力の整理パラメータ}

Fig. 1 に示すように材料 A の半無限板と材料 B の半 無限板を $x$ 軸で接合させた場合を考える。無限板の温 度を零度とし，Fig. 1(a) に示す様に無限板中の領域 $x$ $=-b \sim b, y=-h_{1} \sim h_{2}$ のみを温度 $T\left({ }^{\circ} \mathrm{C}\right)$ に上昇させ る。このときに生ずる熱応力（温度 $T$ を $-T$ とする上 热応力は残留応力と等価となるため，以後は熱応力を残 留応力上呼ぶ.）は図(b)に示すように温度上昇領域の変 位を完全に拘束するのに必要な力 $P_{x}^{A}, P_{y}^{A}, P_{x}^{B}, P_{y}^{B}$ を求 め, 図(c)に示すように镪(b)の力と逆向きの力を無限板に 作用させるとしにより生ずる応力と网(b)の応力を加算す るととより求められる。

図(b)の完全拘束により生じる応打は A 材では

$\varepsilon_{x}^{A}=\varepsilon_{e x}^{A}+\alpha^{A} T=\left\{\sigma_{x}^{A}-\nu^{A}\left(\sigma_{y}^{A}+\sigma_{z}^{A}\right)\right\} / E^{A}+\alpha^{A} T=0$ より,

$$
\varepsilon_{y}^{A}=\varepsilon_{e y}^{A}+\alpha^{A} T=\left\{\sigma_{y}^{A}-\nu^{A}\left(\sigma_{x}^{A}+\sigma_{z}^{A}\right)\right\} / E^{A}+\alpha^{A} T=0
$$

平面応力のときは $\sigma_{z}^{A}=0$ の条件より

$$
\sigma_{x}^{A}=\sigma_{y}^{A}=-E^{A} \alpha^{A} T /\left(1-v^{A}\right)=-P^{A} \text {. }
$$

平面ひずみのときは $\varepsilon A=0$ の条件より

$$
\sigma_{x}^{A}=\sigma_{y}^{A}=\sigma_{z}^{A}=-E^{A} \alpha^{A} T /\left(1-2 \nu^{A}\right)=-P^{A} .
$$

同様にして，B 材では

平面応力の上きは

$$
\sigma_{x}^{B}=\sigma_{y}^{B}=-E^{B} \alpha^{B} T /\left(\mathrm{I}-\nu^{B}\right)=-P^{B} .
$$

平面ひずみのときは

$$
\sigma_{x}^{B}=\sigma_{y}^{B}=\sigma_{z}^{B}=-E^{B} \alpha^{B} T /\left(1-2 \nu^{B}\right)=-P^{B} . \cdots(2-4)
$$

咸(c)の応力は Fig. 2 に示すように無限板中の任意点 （ $\xi ， \eta ）$ に作用している集帆荷重 $w x ， W y$ による応力 の解 ${ }^{5-8)}$ を積分することにより求められる。

集中街重 Wy による解は次式となる。

A 材中の応力

$\sigma_{y}^{A} W^{y} / W y=1 /\left\{2 \pi\left(r^{A}+1\right)\right\} \cdot\left[-\left(k^{A}-1\right)(y-\eta) / r_{1}^{2}\right.$

$-4(y-\eta)^{3 / r_{1}^{4}}+\left\{-2 \mathrm{~m}^{A}\left(\kappa^{A}-1\right) \eta+\left(m^{A} r^{A}-n^{A}\right)(y+\right.$

$\eta)\} / r_{2}^{2}+4 m^{A}(y+\eta)\left\{-6 \eta^{2}+\left(\kappa^{A}+5\right)(y+\eta) \eta-\kappa^{A}(y\right.$

$\left.\left.+\eta)^{2}\right\} / r_{2}^{4}-32 m^{4}(y+\eta)^{3} y \eta / r_{2}^{6}\right]$

$=\int_{y}^{A}\left(\xi, \eta, \nu^{A}, \nu^{B}, m^{A}, n^{A}, x, y\right)$

$\sigma_{x}^{A} W^{y} / W y=1 /\left\{2 \pi\left(r^{A}+1\right)\right\} \cdot\left[\left(k^{A}-1\right)(y-\eta) / r_{1}^{2}-4\right.$

$(y-\eta)(x-\xi)^{2} / r_{1}^{A}-\left\{2 m^{A}\left(\kappa^{A}-1\right) \eta+\left(m^{A} \kappa^{A}-n^{A}\right)(y\right.$

$+\eta)\} / r_{2}^{2}-4 m^{A}\left\{2(y+\eta) \eta^{2}-\left(\kappa^{A}-7\right)(x-\xi)^{2} \eta+\kappa^{A}\right.$

$\left.(y+\eta)(x-\xi)^{2}\right\} / r_{2}^{4}+32 m^{A}(x-\xi)^{2} \eta\{(y+\eta) \eta+(x$ $\left.\left.-\xi)^{2}\right\} / r_{2}^{6}\right]$

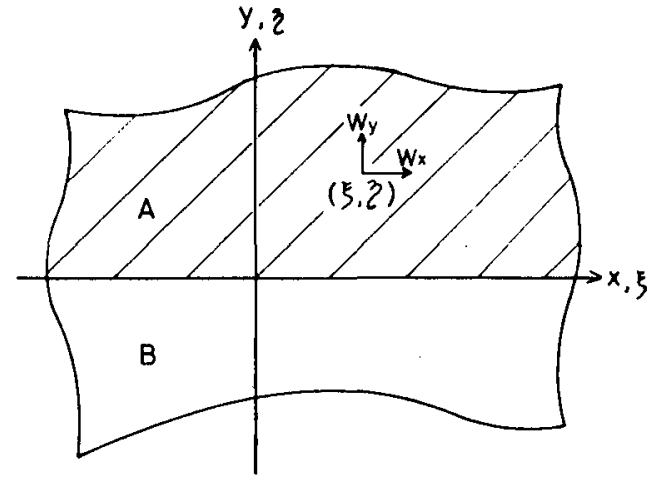

Fig. 2 Concentration force

$=f_{x}^{A}\left(\xi, \gamma_{i}, \nu^{A}, \nu^{B}, m^{A}, n^{A}, x, y\right)$

$\tau_{x y}^{A} W^{y} / W y=(-x+\xi) /\left\{2 \pi\left(\kappa^{A}+1\right)\right\} \cdot\left[\left(\kappa^{A}+3\right) / r_{1}^{2}+\right.$

$4(x-\xi)^{2} / r_{1}^{4}-\left(3 m^{A} r^{A}+n^{A}\right) / r_{2}^{2}+4 \mathrm{~m}^{A}\left\{6 \eta^{2}+\left(\kappa^{A}-5\right) \cdot\right.$

$\left.\left.(y+\eta) \eta+r^{A}(x-\xi)^{2}\right\} / r_{2}^{4}+32 m^{A}(x-\xi)^{2} \eta y / r_{2}^{6}\right]$

$=f_{x y}^{A}\left(\xi, \eta, \nu^{A}, \nu^{B}, m^{A}, n^{A}, x, y\right)$

B 材中の応力

$\sigma_{x}^{B W y} / W y=1 /\left\{2 \pi\left(\kappa^{A}+1\right)\right\} \cdot\left[\left\{-2\left(n^{A}-m^{A}\right) \eta-[(1\right.\right.$ $\left.\left.\left.m^{A}\right) r^{A}-\left(1-n^{A}\right)\right](y-\eta)\right\} / r_{1}^{2}+4\left\{\left(n^{A}-m^{A}\right) \eta-\left(1-n^{A}\right)\right.$. $\left.(y-\eta)\}(y-\eta)^{2} / r_{1}^{4}\right]$

$=g_{y}^{A}\left(\xi, \eta, \nu^{A}, \nu^{B}, m^{A}, n^{A}, x, y\right)$

$\left.\sigma_{x}^{R W y} / W y=1 / 2 \pi\left(x^{A}+1\right)\right\} \cdot\left[\left\{-2\left(n^{A}-m^{A}\right) \eta+[(1-\right.\right.$

$\left.\left.\left.m^{A}\right) r^{A}-\left(1-n^{A}\right)\right](y-\eta)\right\} / r_{1}^{2}+4\left\{\left(n^{A}-m^{A}\right) \eta-\left(1-n^{A}\right)\right.$

$\left.(y-\eta)\}(x-E)^{2} / r_{1}^{4}\right]$

$=\mathrm{g}_{x}^{A}\left(\xi, \eta, \nu^{A}, \nu^{B}, m^{A}, n^{A}, x, y\right)$

$\tau_{x y}^{B} W^{y} / W y=(-x+\xi) /\left\{2 \pi\left(\kappa^{A}+1\right)\right\} \cdot\left[\left\{-\left(1-m^{A}\right) \cdot\right.\right.$

$\left.r^{A}-3\left(1-n^{A}\right)\right\} / r_{1}^{2}+4\left\{\left(n^{A}-m^{A}\right)(y-\eta) \eta+\left(1-n^{A}\right)(x\right.$

$\left.\left.-\xi)^{2}\right\} / r_{1}^{4}\right]$

$=g_{x y}^{A}\left(\xi, \eta, \nu^{A}, \nu^{B}, m^{A}, n^{A}, x, y\right)$

集中荷重 $W x$ による解は次式となる。

A 材中の応力

$\sigma_{y}^{A} W^{x} / W x=(x-\xi) /\left\{2 \pi\left(\kappa^{A}+1\right)\right\} \cdot\left[\left(\kappa^{A}-1\right){ }^{\prime} r_{1}^{2}-4\right.$

$(y-\eta)^{2} / r_{1}^{4}-\left(m^{A} \kappa^{A}-n^{A}\right) / r_{2}^{2}+4 m^{A}\left\{2 \eta^{2}+\left(\kappa^{A}-1\right) \cdot\right.$

$\left.\left.(y+\eta) \eta-r^{A}(y+\eta)^{2}\right\} / r_{2}^{4}+32 m^{A}(y+\eta)^{2} y \eta / r_{2}^{6}\right]$

$=c_{y}^{A}\left(\xi, \quad \eta, \quad y^{A}, \nu^{B}, m^{A}, n^{A}, x, y\right)$

$\sigma_{x}^{A} W^{x} / W_{x}=(x-\xi) /\left\{2 \pi\left(x^{A}+1\right)\right\} \cdot\left[-\left(x^{A}+3\right) / r_{1}^{2}\right.$

$+4(y-\eta)^{2} / r_{1}^{4}-\left(3 m^{A} \kappa^{A}+n^{A}\right) / r_{2}^{2}-4 m^{A}\left\{2 \eta^{2}-\left(5-\kappa^{A}\right)\right.$.

$\left.\left.(y+\eta) \eta-r_{1}^{A}(y+\eta)^{2}\right\} / r_{2}^{4}-32 m^{A}(y+\eta)^{2} y \eta / r_{2}^{6}\right]$

$=c_{x}^{A}\left(\varepsilon, \eta, \nu^{A}, \nu^{B}, m^{A}, n^{A}, x, y\right)$

$\tau_{x_{y}}^{A} W^{x} / W x=1 /\left\{2 \pi\left(\kappa^{A}+1\right)\right\} \cdot\left[\left(\kappa^{A}+3\right)(y-\eta) / r_{1}^{2}\right.$

$-4(y-\eta)^{3} / r_{1}^{4}-\left\{2 m^{A}\left(r^{A}-1\right) \eta-\left(3 m^{A} r^{A}+n^{A}\right)(y+\right.$

$\eta)\} / r_{2}^{2}-4 m^{A}(y+\eta)\left\{-6 \eta^{2}+\left(7-\kappa^{A}\right)(y+\eta) \eta+x^{A}\right.$.

$\left.\left.(y+\eta)^{2}\right\}_{1}^{\prime} r_{2}^{4}+32 m^{A}(y+\eta)^{3} y \eta / r_{2}^{6}\right]$

$=c_{x y}^{A}\left(\varepsilon, \eta, \nu^{A}, \nu^{B}, m^{A}, n^{A}, x, y,\right)$

B 材中の応力

$\sigma_{y}^{R W^{x}} / W^{T} x=(x-\xi) /\left\{2 \pi\left(\kappa^{A}+1\right) \cdot\left[\left\{\left(1-m^{A}\right) r^{A}-(1\right.\right.\right.$

$\left.\left.-n)^{A}\right\} / r_{1}^{2}+4(y-\eta)\left\{\left(n^{A}-m^{A}\right) \eta-\left(1-n^{A}\right)(y-\eta)\right\} / r_{1}^{A}\right]$

$=\mathrm{d}_{y}^{A}\left(\xi, \eta \eta, \nu^{A}, \nu^{B}, m^{A}, n^{A}, x, y\right)$

$\sigma_{x}^{B} W^{x} / W x=(x-\xi) /\left\{2 \pi\left({ }^{A}+1\right)\right\} \cdot\left[\left\{-\left(1-m^{A}\right)\right.\right.$.

$\left.n^{A}-3\left(1-n^{A}\right)\right\} / r_{1}^{2}-4(y-\eta)\left\{\left(n^{A}-m^{A}\right) \eta-\left(1-n^{A}\right) \cdot\right.$

$\left.(y-\eta)\} / r_{1}^{4}\right]$

$=d_{x}^{A}\left(\xi, n, \nu^{A}, \nu^{B}, m^{A}, n^{A}, x, y\right)$ 
$\tau_{x y}^{H} W^{x} / W x=1 /\left\{2 \pi\left(n^{A}+1\right)\right\} \cdot\left[-\left\{2\left(n^{A}-m^{A}\right) r_{i}-\right.\right.$ $\left.\left(\kappa^{A}-m^{A} x^{A}+3-3 n^{A}\right)(y-\eta)\right\} / r_{1}^{2}+4(y-\eta)^{2}\left\{\left(n^{A}-m^{A}\right)\right.$. $\left.\left.\eta-\left(1-n^{A}\right)(y-\eta)\right\} / r_{1}^{4}\right]$

$=d_{x y}\left(\xi, \eta, \nu^{A}, \nu^{R}, m^{A}, n^{A}, x, y\right)$

ただし， $r_{1}^{2}=(x-\xi)^{2}+(y-\eta)^{2}, r_{2}^{2}=(x+\xi)^{2}+(y-$ $\eta)^{2} m^{A}=(1-\Gamma) /\left(\Gamma{ }^{A}+1\right)=m^{A}\left(\nu^{A}, \nu^{A}, E^{A}, E^{B}\right)$ $n^{A}=\left(\kappa^{B}-{ }^{A} \Gamma\right) /\left(\Gamma+{ }^{B}\right)=n^{A}\left(\nu^{A}, \nu^{B}, E^{A}, E^{B}\right) \cdots(5)$

集中加が材料 B の中にあるとさは式(3)，(4)，(5)0添 え字 $A$ ，上 $B$ を入れ換えればよい。

Fig.1(c)の分布荷重 $P_{y}^{A}$ による圭力は式(3)において $W_{y}$

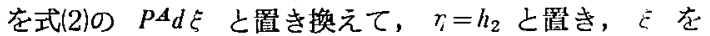
$-b$ から $b$ まで積分すれば求められる。例えば，A 材の $x$ 軸方向の垂直充力 $\left.\sigma_{x}\left(P_{y}^{A}\right)\right)$ は式 (3-2) より，

$\sigma_{x}\left(P_{y}^{A}\right)=P^{A} \cdot \int_{-b}^{b} f_{x}^{A}\left(\xi, h_{2}, \nu^{A}, \nu^{B}, m^{A}, n^{A}, x, y\right) d \xi$

$=P^{A} \cdot \int_{-1}^{1} f_{x}^{A}\left(\xi / b, h_{2} / b, \nu^{A}, \nu^{B}, E^{B} / E^{A}, x / b, y / b\right) d(\xi / b)$

$=P A \cdot F_{x}^{A}\left(h_{2} / b, \nu^{A}, \nu^{B}, E^{B} / E^{A}, x / b, y / b\right) \cdots(6-1)$

同样にして, $-P_{y}^{A}, P_{x}^{A},-P_{x}^{A}, P_{y}^{B},-P_{y}^{B}, P_{x}^{B},-P_{x}^{B}$ に 上る $\mathrm{A}$ 材の $x$ 軸方向の垂直応力 $\sigma_{x}\left(-P_{y}^{A}\right), \sigma_{x}\left(P_{x}^{A}\right)$, $\sigma_{x}\left(-P_{x}^{A}\right), \sigma_{x}\left(P_{y}^{B}\right), \sigma_{x}\left(-P_{y}^{B}\right), \sigma_{x}\left(P_{x}^{B}\right), \sigma_{x}\left(-P_{x}^{B}\right)$ は 式 (3-2), (4-2), (4-2), (3-5), (3-5), (4-5), (4-5) より次式の関数形となる.

$$
\begin{array}{r}
\sigma_{x}\left(-P_{y}^{A}\right)=-P^{A} \cdot F_{x}^{A}\left(0, \nu^{A}, \nu^{B}, E^{B} /{ }^{A} E, x / b, y / b\right) \\
\cdots \cdots(6-2) \\
\sigma_{x}\left(P_{x}^{A}\right)=P A \int_{0}^{h_{2} / b} c_{x}^{A}\left(\eta / b, \nu^{A}, \nu^{B}, E^{B} / E^{A}, x / b,\right. \\
y / b) d(\eta / b)=P^{A} \cdot C_{x}^{A}\left(h_{2} / b, \nu^{A}, \nu^{B}, E^{B} / E^{A}, x / b, y / b\right) \\
\cdots \cdots(6-3) \\
\sigma_{x}\left(-P_{x}^{A}\right)=-P^{A} \cdot C_{x}^{A}\left(h_{2} / b, \nu A, \nu^{B}, E^{B} / E^{A}, x / b, y / b\right) \\
\cdots \cdots(6-4) \\
\sigma_{x}\left(P_{y}^{B}\right)=P_{B} \int_{-1}^{1} g_{x}^{B}\left(\xi / b, \nu \nu^{A}, E^{B} / E^{A}, x / b, y / b\right) \\
d(\xi / b)=P_{B} \cdot G_{x}^{B}\left(0, \nu^{A}, \nu^{B}, E^{B} / E^{A}, x^{\prime} / b, y / b\right) \cdots(6-5) \\
\sigma_{x}\left(-P_{y}^{B}\right)=-P_{B} \cdot G_{x}^{B}\left(h_{1} / b, \nu^{A}, \nu^{B}, E^{B} / E^{A}, x / b, y / b\right) \\
\cdots \cdots(6-6) \\
\sigma_{x}\left(P_{x}^{B}\right)=P_{B} \cdot \int_{-h_{1} / b}^{0} d_{x}^{B}\left(\eta / b, \nu^{A}, \nu^{B}, E^{B} / E^{A}, x / b, y / b\right) \\
=P_{B} \cdot D_{x}^{B}\left(h_{1} / b, \nu^{A}, \nu^{B}, E^{B} / E^{A}, x / b, y / b\right) \quad \cdots \cdots(6-7) \\
\sigma_{x}\left(-P_{x}^{B}\right)=-P_{B} \cdot D_{x}^{B}\left(h_{1} / b, \nu^{A}, \nu^{B}, E^{B} / E^{A}, x / b, y / b\right)
\end{array}
$$

式(2)，(6)上り，Fig. 1(a) で生ずる領域 A 材の応」 $\sigma_{x}$ は次式の関数形となる。

$\sigma_{x} / P^{A}=F\left(h_{2} / b, h_{1} / b, \nu^{A}, \nu^{B}, E^{B} / E^{A}, x / b, y / b, P^{B} / P^{A}\right)$ $=G\left(h_{2} / b, h_{1} / b, \nu^{A}, \nu^{B}, E^{B} / E^{A}, x / b, y / b, \alpha^{B} / \alpha^{A}\right) \cdots \cdots(7)$ 以上の方法を他の応力の計算に李適用すると結論として 応力は式(7)の関数で与えられるととが証明できる。

徉って, 残留応力 $\sigma / P^{A}\left(P^{A}\right.$ の大きさは平面忘力では $E^{A} \alpha^{A} T /\left(1-\nu^{A}\right)$, 平面ひずみでは $E^{A} \alpha^{A} T /\left(1-22^{A}\right)$ は

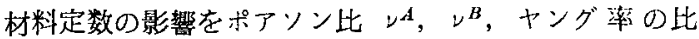
$E^{B} / E^{B}$, 線膨張係数の比 $\alpha^{B} / \alpha^{A}$ の関数形で受ける。ま た，残留応力は $h_{2} / b, h_{1} / b, x / b, y / b$ 上り相似形では相 似点で同じとなる。

\section{3. パラメータの有効性}

\section{1 相似則}

二節で明らかになったパラメータから導かれる最毛熏 要な結論は相似則である．相似体において相似点での残 留応力が等しければ，等しい外応力により生じる枕少

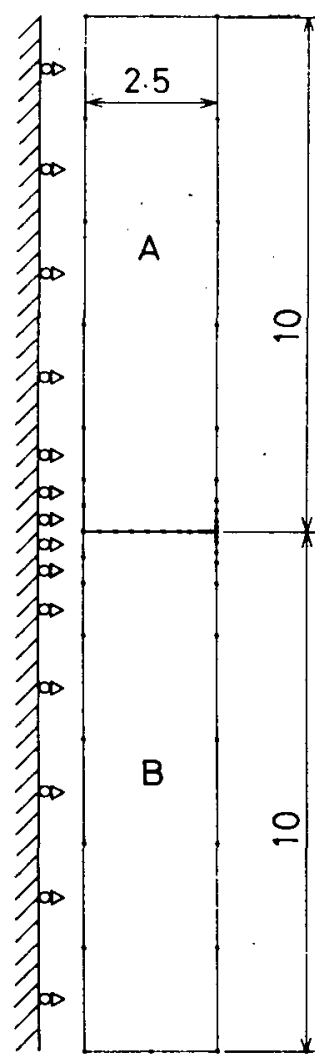

(a)

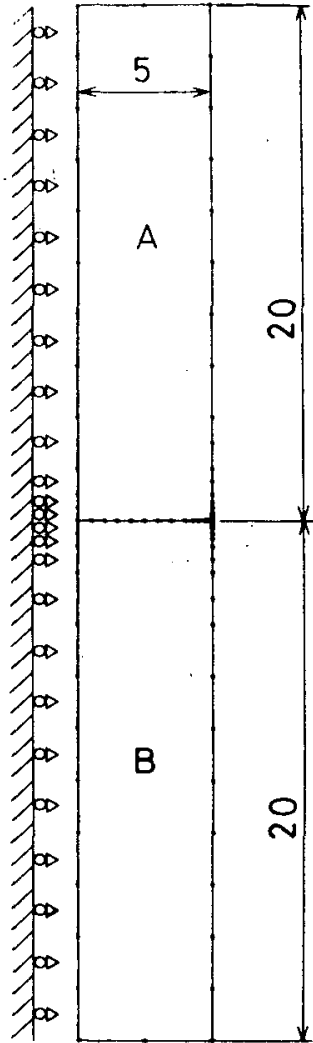

(b)
Fig. 3 Mesh division

(a) Materials $A$ and $B$ are $5 \mathrm{~mm}$ width and $10 \mathrm{~mm}$ height, respectively.

(b) Materials A and B are $10 \mathrm{~mm}$ width and $20 \mathrm{~mm}$ height, respectively.

相似点で等しいため (付録参照)，扣算則により相似点 に発生する応力は等しくなる。このため，相似形の界面 接合継手の強度を考える場合は，強度が應力で决定され る時にはす法効果の影掣を受けないことになる。

強度力゙応力拡大係数のような破廈力学のパラメータや エネルギー密度で決まる時には寸法効果が現れる。

有限板においても相似則が成立することを証明する。 平居が作成した境界要素法のブログラムを用いて, 二枚 の異種材料の有限板を抬散接合したときの残留応力を数 値解析する (平居のプログラムで精度良く解析できる 事を付録认示している.).Fig. 3(a)，(b) は数值解析に用 いた相似体の要素分割図である。幅 $5 \mathrm{~mm}$, 高さ $10 \mathrm{~mm}$ の板 A，B 材を接合した場合（図(a)）と幅 $10 \mathrm{~mm}$, 高 さ $20 \mathrm{~mm}$ の板 $\mathrm{A}, \mathrm{B}$ を接合した場合（図(b)）を平面灾 力状態で解析した，A，B 材の線膨張係数; ヤング榽， ポアソン比はそれぞれ $2 \times 10^{-5} K^{-1}, 1 \times 10^{-5} K^{-1} ; 20000$ $\mathrm{MPa}, 20000 \mathrm{MPa} ; 0.3,0.3$ である.Fig. 4(a) は接含界 面 $(y=0)$ に生じる残貿応力 $\sigma_{x}, \tau_{x y}$ を示している. A， B 村の残留応力 $\tau_{x y}, \sigma_{y}$ は界面で等しく，境界条件 を型足している. Fig. 4 (b) に $x=b$ 断面での残留志力 $\sigma_{y}^{A}$ を亦す. Fig. 4 より残留念力は相似点で等しいこ 
とが分かる。また, 界面上 $(y=0)$ では界面に画值な残 留志打 $\sigma_{y}$ は零であり，せん断芯打 $\tau_{x y}$ は界面の端部近

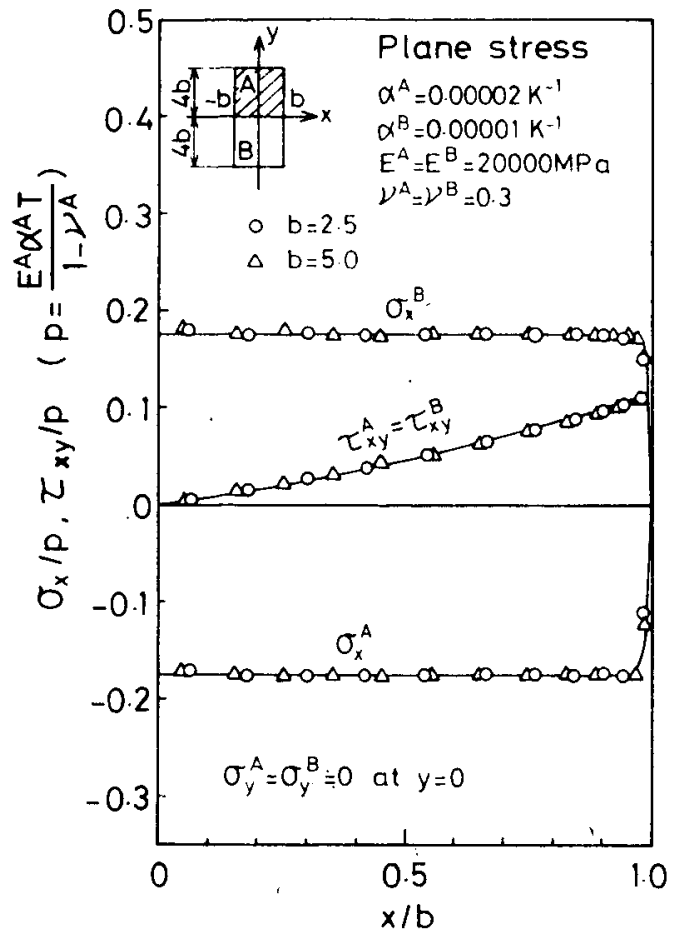

(a)
浐で大きな㑷になる、 $x=b$ の断面上において残留応力 $\sigma_{y}$ は界面 $(y=0)$ の近傍で大きな倠を取ることが分か 乃.

3.2 線起張係数の比，ヤング率の比およびポアンン比 二節上り残留応力 $\sigma / P^{A}\left[P^{A}\right.$ の大きさは平面応力では $E^{A} \alpha^{A} T /\left(1-\nu^{A}\right)$, 平面ひずみでは $\left.E^{A} \alpha^{A} T /\left(1-2 v^{A}\right)\right]$

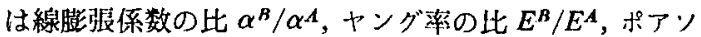
比 $\nu^{A}, \nu^{\prime \prime}$ で整理できる. Table 1 は残留応力 $\sigma / P A$ が因子 $\alpha^{B} / \alpha^{A}, E^{B} / E^{A}, \nu^{A}, \nu^{n}$ で整理できることを境 界要泰法で碓認した計算結果である。計算はTable 1 の

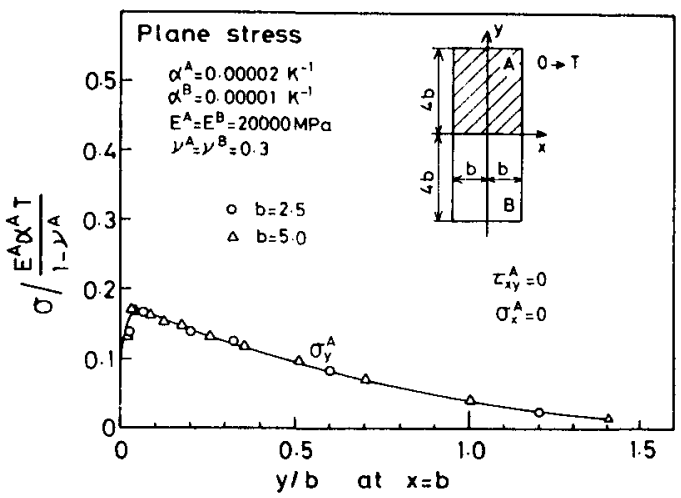

(b)

Fig. 4 Distributions of residual stress

(a) Bond line

(b) Edge line of material A

Table 1 Galculation results obtained by Boundary Element Method (BEM)

\begin{tabular}{|c|c|c|c|c|c|}
\hline & & $\sigma_{x}{ }^{A} /\left[E^{A} \alpha^{A} T\right.$ & $\left.\left(1-v^{A}\right)\right]$ & & \\
\hline & (1) & (2) & (3) & (4) & (5) \\
\hline$x / b$ & $\begin{aligned} \alpha{ }^{\mathrm{A}} & =0.00002 \mathrm{~K}^{-1} \\
\alpha^{\mathrm{B}} & =0.00001 \mathrm{~K}^{-1} \\
\mathrm{E}^{\mathrm{A}} & =20000 \mathrm{MPa} \\
E^{\mathrm{B}} & =20000 \mathrm{MPa} \\
\nu^{\mathrm{A}} & =0.3 \\
\nu^{\mathrm{B}} & =0.3\end{aligned}$ & $\begin{array}{l}\alpha^{A}=0.002 K^{-1} \\
\sim^{\alpha^{B}}=0.001 K^{-1} \\
E^{A}=20000 \mathrm{MPa} \\
E^{B}=20000 \mathrm{MPa} \\
\nu^{A}=0.3 \\
\nu^{B}=0.3\end{array}$ & $\begin{aligned} \alpha^{A} & =0.00002 K^{-1} \\
\alpha^{B} & =0.00001 K^{-1} \\
E^{A} & =20000 \mathrm{MPa} \\
E^{B} & =20000 \mathrm{MPa} \\
\nu^{A} & =0.3 \\
\nu^{B} & =0.5\end{aligned}$ & $\begin{aligned} \alpha^{A} & =0.00002 K^{-1} \\
\alpha^{B} & =0.00001 K^{-1} \\
E^{A} & =20000 \mathrm{MPa} \\
\tilde{E}^{B} & =100000 \mathrm{MPa} \\
\nu^{A} & =0.3 \\
\nu^{B} & =0.3\end{aligned}$ & $\begin{array}{l}\alpha^{A}=0.00002 K^{-1} \\
\alpha^{B}=0.00001 K^{-1} \\
\underbrace{E^{A}}=200 \\
\underbrace{E^{B}}=1000 \\
\nu^{A}=0.3 \\
\nu^{B}=0.3\end{array}$ \\
\hline 0.98 & -0.1131 & -0.1129 & -0.0775 & -0.2379 & -0.2375 \\
\hline 0.94 & -0.1779 & -0.1779 & -0.1808 & -0.2767 & -0.2766 \\
\hline 0.90 & -0.1752 & -0.1747 & -0.1738 & -0.2634 & -0.2634 \\
\hline 0.84 & -0.1750 & -0.1751 & -0.1740 & -0.2608 & -0.2608 \\
\hline 0.76 & -0.1750 & -0.1750 & -0.1734 & -0.2598 & -0.2598 \\
\hline 0.66 & -0.1750 & -0.1749 & -0.1731 & -0.2603 & -0.2604 \\
\hline 0.54 & -0.1750 & -0.1750 & -0.1730 & -0.2614 & -0.2614 \\
\hline 0.42 & -0.1750 & -0.1750 & -0.1727 & -0.2625 & -0.2624 \\
\hline 0.30 & -0.1751 & -0.1751 & -0.1727 & -0.2631 & -0.2632 \\
\hline 0.18 & -0.1749 & -0.1749 & -0.1727 & -0.2638 & -0.2638 \\
\hline 0.06 & -0.1704 & -0.1704 & -0.1646 & -0.2609 & -0.2610 \\
\hline
\end{tabular}

$\alpha$ : Coefficient of linear expansion

E: Young's modulus

$v$ : Poisson's ratio 
上欄に示した材料定数を用いて，Fig. 3.(a) の要素分 制 で平面応力解析で行った，列(1)，(2)では線膨苌係数の比 $\alpha^{B} / \alpha^{A}$ を0.5として，線路張係数の絶対值を二杕変化さ せたときの結果を示している．場所 $x / b$ が同じ点での残

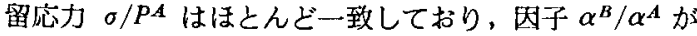
有効であることが分かる，列(4)，(5)ではヤング染の比 $E^{B} / E^{A}$ を 5 として，ヤング率の絶刘值を二桁変化させた ときの数值解析結果を示している．数值がほぼ一致して おり因子 $E^{B} / E^{A}$ は有效である。列(31列(1)対してポ アソン比 $\nu^{B}$ を. 3から0.5に変化させた時の計算結果で ある、ポアソン比ン ${ }^{B}$ により残留応力が変化している。

以上より残留応力 $\sigma / P^{A}$ は線膨張係数の比 $\alpha^{B} / \alpha^{A}$, ヤング率の比 $E^{B} / E^{A}$ ，ポアソン比 $\nu^{A} ， \nu^{B}$ で整理でき るととが証明された。

\section{4. 結 論}

本論文で得られた結論を要約する。

(1) 残留応力 $\sigma / P^{A}\left[P^{A}\right.$ の大きさは平面応力では $E^{A} \alpha^{A} T /\left(1-\nu^{A}\right)$, 平面ひずみでは $\left.E^{A} \alpha^{A} T /\left(1-2 \nu^{A}\right)\right]$ は材料定数の影掣をポアンン比 $\nu^{A}, \nu^{B}$, ヤング率の比 $E^{B} / E^{A}$ ，楾膨張係数の比 $\alpha^{B} / \alpha^{A}$ の関数形で受ける（式 (7), Table 1 参照).

(2) 牫留応力は相似形では相似点で同じとなる（Fig. 4 参照). このため，相似形の界面接合継手の強度を考え る場合は，強度が応力で決定される場合には寸法効果の 影幚を受けないとと，強度が応力搪大係数のような破壊 力学のパラメータやエネルギー密度で決まる場合には寸 法效果が表れることが予想される。

付録 境界要厤法プログラムの精度について 異種材料の界面に生ずる応力は材料定数の相違により 応力の特異性を示す。このため接合界面の応力を精度良 く解析するためには有限要素法より6境界要素法（BE $\mathrm{M}$ 亡呼ぶ）の方が優れている。用いた BEM プログラ ムの精度を検討するために Bogy の理論解と数值解を比

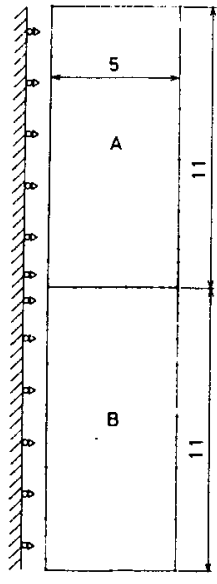

(a)

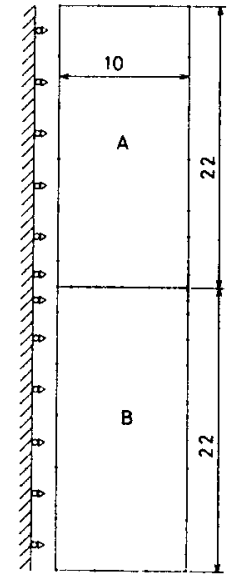

(b)
Fig. A Mesh division

(a) Small size specimen for verifying similar law

(b) Large size specimen for verifying similar law
（3）拻散接合において生ずる残留忍力は界面上 $(y=0)$ では界面に垂直な残留応力 $\sigma_{y}$ は㛚であり，せん断応打 $\tau_{x y}$ は界面の端部近傍で大きな值になる，界面の端部 $x=b$ の断面上において残留応力 $\sigma_{y}$ は界面 $(y=0)$ の近 傍で大きな值を取ることが分かる（Fig.4 参照）。

謝辞 本研究は中村治方主查の IJ 委員会で討論して いただいた、本研究の一部は実吉奖学金で成された、記 して謝意を表する。

\section{参 考 文 献}

1) D. B. Bogy, Edge-Bonded Dissimilar Orthogonal Elastic Wedges Under Normal and Shear Loading. J. Appl. Mech. Vol. 35, 460 (1968).

2) J. Dundurs, Discussion, J. Appl. Mech., Vol. 36, 650 (1969).

3) D. B. Bogy, The Plane Solution for Joined Dissimilar Er lastic Semistrips Under Tension, J. Appl. Mech. Vol. 42, 93 (1975).

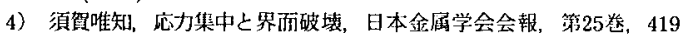
(1986).

5) J. T. Frasier and L. Rongved, Force in the Plane of Two Joined Semi-Infinite Plates, J. Appl. Mech., Vol. 24, 582 (1957).

6) J. Dundurs and M. Hetenyi, The Elastic Plane With a Circular Insert, Loaded by a Radial Force, J. Appl. Mech., Vol. 28, 103 (1961).

7) M. Hetenyi and J. Dundurs, The Elastic Plane With a Circular Insert, Loaded by a Tangentially Directed Force, J. Appl. Mech., Vol. 29, 362 (1962).

8）北川英夫，結城终治，神原静夫，翼材境界在横切る有限板山のき 裂の応力抆大係数，日本機械学会論文集 $(\mathrm{A}$ 綪)，45巷，1024 (1979).

9）平居孝之，弾性解析プログラムとその使い方，理工图㫪，1984

較した ${ }^{3)}$. Fig.A(a)，(b) に相似体の要素分割浽を示す。

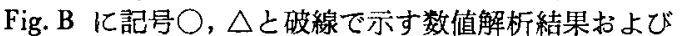
実線の Bogy の理論解を示す。 Bogy の理論解は幅 $2 \mathrm{z}$, 高さ半無限板の二枚の板を接合して無限遠に外心力 $p$ を作用させたときの解である，理論解之数值解析結果は ほぼ一致していることおよび相似則が成立していること が分かり，本論文で用いたプログラムの精度は良いと思 われる。

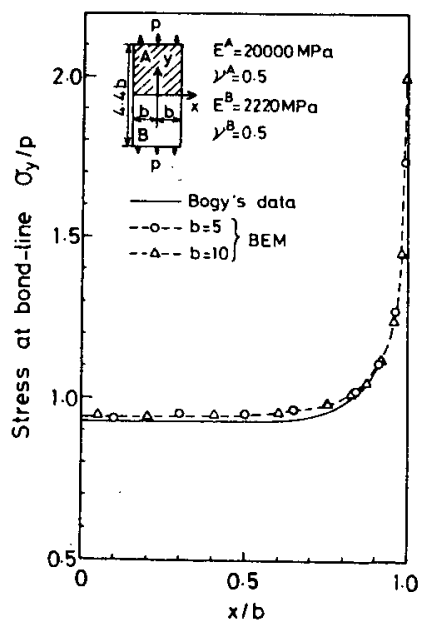

Fig. B Comparison between Bogy's data and numerical results by $\mathrm{BEM}$ 